\title{
PRESENT APPROACHES TO LANDSCAPE TYPOLOGY IN THE CZECH REPUBLIC
}

\author{
DUŠAN ROMPORTL, TOMÁŠ CHUMAN
}

Department of Physical Geography and Geoecology, Faculty of Science, Charles University in Prague, Albertov 6, 12843 Praha 2, email: dusan@natur.cuni.cz.

Received: $27^{\text {th }}$ February 2012, Accepted: $18^{\text {th }}$ December 2012

\begin{abstract}
Landscape typologies are widely recognised as useful tools for landscape management and planning. However, there is wide range of different approaches producing diverse outputs, which makes the usage of landscape typologies sometimes difficult or confusing in general practice (Wascher ed., 2005). The same situation is found in the Czech Republic, where a number of holistic, expert-based and quantitative approaches were developed. These differences could be explained by different objectives of landscape classification, different input data and methods used, and by the particular author's experience and erudition. Nevertheless, landscape typology should be clear both for scientists, landscapeplanners and policy makers. It is necessary to create valid landscape-planning documents which have to reflect regional, cultural and natural landscape specifics, for as effective and sustainable land use as possible. For such a strategic planning, clearly defined and characterised spatial units seem to be an essential base. This paper aims to introduce the fundamental methodological approaches, provides basic comparison of different Czech typologies, and discusses an optimal method for landscape planning.

Key words: landscape typology, object oriented image analysis, cluster analysis, Czech Republic
\end{abstract}

\section{INTRODUCTION}

Landscape sphere as a heterogeneous system could be sorted into the spatial units in different ways. Some authors (e.g. Pinto-Correia et al. 2006, Palang et al. 2006) draw attention to the uniqueness of landscapes and therefore define rather the individual units. Others (e.g. Metzger et al. 2005, Bunce et al. 1996) point to the repeatability of landscape phenomena and processes in relatively homogeneous units, therefore prefer typological approaches. The only common rule is to respect the principle of landscape complexity, to take into account the whole set of environmental conditions, including zonal and azonal specifics, history of development, causes and conditions of territorial differentiation (Kolejka, 1999). However, definition of landscape spatial units needs to be based on simple synthetic indicators when possible, which have to provide sufficient information at the same time. Individual sciences dealing with landscape or its components, such as geomorphology, botany or landscape architecture, work with particular classification signs and scales. Similarly, various landscape users define its values diametrically differently; a 
farmer divides and evaluates the landscape at the city outskirts in a different way than a developer of a new suburban area. A cultural landscape such a complex object, is therefore hardly quantified in all aspects (Bastian, 2000).

Delineation and characterisation of landscape typological regions could be provided by three basic methodological approaches: (1) holistic typologies - based on general perception of landscapes by experts, stakeholders or decision makers (Antrop \& VanEetvelde 2000, Palang et al. 2006, Spiegler1998); (2) expert statement typologies multi-criteria classification of landscape factors carried out by experts (e.g. Demek et al. 1977, Culek 2005, Meuss 1995) and finally (3) quantitative typologies - processed by mathematical and statistical methods using GIS tools (Bunce et al. 1996, Metzger et al. 2005, Mücher et al. 2003, Van Eetvelde \& Antrop, 2009a, Chuman \& Romportl 2010, Romportl 2010).

A wide range of methodological approaches is used to define landscape types as well as different landscape factors; therefore a comprehensive overview of them is shown, as along with data availability in the Czech Republic.

\section{DRIVING LANDSCAPE FACTORS AND DATASETS USED FOR LANDSCAPE TYPOLOGIES}

European cultural landscape is a result of both natural and anthropogenic processes, whose impact is reflected in physiognomy of landscape types as well as in their functional aspects. Methods of landscape typology could vary as described above, but almost all of them work on the principle of a synthesis of information on landscape character. What makes the real difference of classification outputs is the choice of driving landscape factors and their weight assignment. Simple conceptual models describing relationships between natural and cultural factors are often used for proper choice of variables used for landscape typology (e.g. Kolejka 1999, Metzger et al. 2005, Mücher et al. 2003). According to the dependency of particular components, functional hierarchy is shown (figure 1).

Fig. 1: Functional hierarchy of abiotic, biotic and cultural components defining landscape type (after Kolejka 1999 and Mücher et al. 2003)

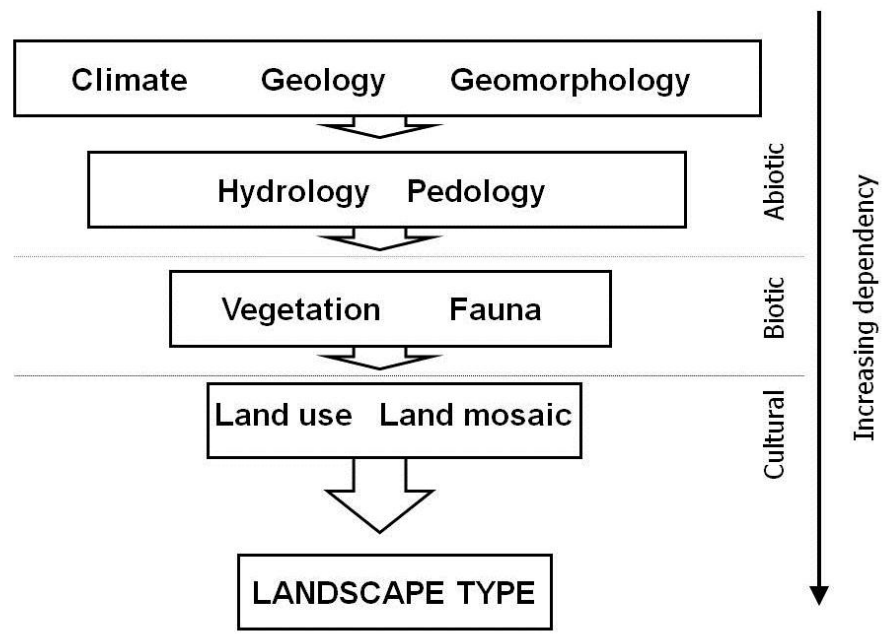




\section{Data on natural factors}

\section{Climate}

Climate presents an essential factor affecting most of the other natural processes, and directly influences topography, hydrography, soil development and runoff regime, and also determines distribution of species and ecosystems. Climatic variables are therefore widely recognised as the driving element in large- and mezzo-scale landscape typologies (Metzger et al. 2005).

\section{Geological and substrate conditions}

Geological material influences, by its physical and chemical properties, other natural elements such as topography, soil types, groundwater reserves or vegetation, and indirectly determines a character and intensity of the land use (Mücher, 2010). Information about substrate type therefore becomes a common base for complex typology processing, but nevertheless it differs on generalisation level (e.g. Kolejka 1999, Van Eetvelde \& Antrop, 2009).

\section{Geomorphology}

Topographic parameters - primarily altitude, slope and exposition - directly influence other landscape elements and processes and determine micro- and mezoclimatic conditions, land development, drainage conditions, vegetation zones and land use possibilities (Peterseil, 2004). Geomorphologic and topographical data therefore become a vital base for a landscape typology, which is enabled by the help of effortless availability of suitable database. For a landscape typology formation, various digital terrain models (DTM) are mostly used, which are freely provided in a sufficient resolution.

\section{Hydrography}

Surface water distribution is an essential geographical, ecological and aesthetical factor. Rivers represent important corridors both for biota and human society. Simultaneously, flood occurrences, erosive and sedimentation processes, biological invasions phenomena, etc. are bound to them (Wascher ed. 2005). Despite the indisputable influence on the landscape character, hydrographic data are marginalised in a landscape typology data mainly due to its line character. Area segments of surface waters are reflected in the land use assessment, and water flows are occasionally assessed by a grid of water flows density (Wascher ed.2005).

\section{Vegetation}

Data on current or potential vegetation is an essential information source of biotopes quality, eventually of its degradation rate and a real or potential biodiversity. Potential natural vegetation should be an inevitable base for a natural landscape type definition, if typology is used as a base for restoration programmes and recultivation. At a regional and local level it gives us information about climatic and substrate conditions.

\section{Fauna}

The last natural landscape component presents a dependent variable and only a minimum attention is therefore paid to it in a landscape typology. Population size and density, diversity and possibilities of dispersion and migration of particular organism species of all taxonomic groups are a frequent research subject of ecological disciplines; however there is not enough relevant data for usage in landscape classification. 


\section{Data on cultural factors}

\section{Land use}

Data on land use is the last inevitable information source of a complex landscape typology. The land use indicates a specific distribution of human activities in space and so predicates about the anthropogenic effect rate. The most common formulation of a current landscape use is constant typological classification which is regularly updated on methodically standardized data collection.

\section{Landscape structure}

Information about secondary landscape structure predicates about a specific way of land use by humans in existing natural conditions of particular regions. Landscape structure and character also reverts to a historical development of a given landscape. The basic landscape metric, meaning the size and the shape of particular patches as well as matrix, their fragmentation and connectivity rate, heterogeneity, landscape openness or closeness, all have a fundamental impact on an overall landscape character. The landscape structure also influences the character of energy and material flows and organisms fluctuation alternatives.

Spatial representation of a secondary landscape structure, therefore, should be an important typology base. However, there are no fixed methods for its evaluation. Most frequently used are layers of landscape heterogeneity, derived from data on land cover.

\section{Settlement character and structure}

The historical development of the settlement and the character of an agricultural area and settlement organization is undoubtedly relevant information for the needs of a landscape character assessment. Their exact spatial representation, and therefore use in a landscape typology, is nevertheless controversial. Categories of a settlement character are not logically clearly definable; likewise in the case of the climate where the boundaries among residential districts are of a continual character and therefore hardly determinable.

Environmental factors and their representation in current databases often used in the Czech Republic are shown in Table 1.

\begin{tabular}{|c|c|c|c|}
\hline $\begin{array}{l}\text { Environmental } \\
\text { factor }\end{array}$ & Name of database & $\begin{array}{l}\text { Datasets suitable for } \\
\text { landscape classification }\end{array}$ & Scale \\
\hline Climate & $\begin{array}{l}\text { Climate Atlas of } \\
\text { Czechia (Tolasz et al., } \\
\text { 2007) }\end{array}$ & $\begin{array}{l}\text { annual mean temperature, } \\
\text { annual mean precipitation, } \\
\text { climatic regionalization }\end{array}$ & $1: 1.000 .000$ \\
\hline Geology & $\begin{array}{l}\text { GEOČR } 500 \text { (Zoubek } \\
\text { et al., 2003) }\end{array}$ & geology map & $1: 500.000$ \\
\hline Soils & $\begin{array}{l}\text { Soil Atlas of the Czech } \\
\text { Republic (Kozák et al., } \\
\text { 2009) }\end{array}$ & several soil maps & $1: 500.000$ \\
\hline Geomorphology & $\begin{array}{l}\text { SRTM DEM (USGS) } \\
\text { ZABAGED (ČUZZK) }\end{array}$ & digital elevation models & pixel $10-100 m$ \\
\hline Hydrography & $\begin{array}{l}\text { DIBAVOD } \\
\text { TGM, 2009) }\end{array}$ & $\begin{array}{l}\text { digital base of water } \\
\text { objects }\end{array}$ & $1: 10.000$ \\
\hline
\end{tabular}




\begin{tabular}{|c|c|c|c|}
\hline $\begin{array}{l}\text { Potential } \\
\text { vegetation }\end{array}$ & $\begin{array}{l}\text { Map of the Potential } \\
\text { Natural Vegetation } \\
\text { (Neuhäuslová et al. } \\
\text { 1999) }\end{array}$ & $\begin{array}{l}\text { digital map of potential } \\
\text { vegetation of the Czech } \\
\text { Republic }\end{array}$ & $1: 500.000$ \\
\hline $\begin{array}{l}\text { Reconstructed } \\
\text { natural vegetation }\end{array}$ & $\begin{array}{l}\text { Map of reconstructed } \\
\text { natural vegetation of } \\
\text { the Czech Republic } \\
\text { (Mikyška et al., 1968- } \\
\text { 1972) }\end{array}$ & $\begin{array}{lr}\text { digital map } & \text { of } \\
\text { reconstructed } & \text { natural } \\
\text { vegetation } & \\
\text { lation }\end{array}$ & 1: 200.000 \\
\hline Fauna & $\begin{array}{l}\text { National Database of } \\
\text { species distribution } \\
\text { (ANCLP, 2009) }\end{array}$ & $\begin{array}{l}\text { several species distribution } \\
\text { maps }\end{array}$ & different scales \\
\hline Land use/cover & $\begin{array}{l}\text { CORINE Land Cover } \\
2006\end{array}$ & $\begin{array}{l}\text { categorical map of land } \\
\text { cover types }\end{array}$ & $1: 100.000$ \\
\hline $\begin{array}{l}\text { Landscape } \\
\text { structure }\end{array}$ & $\begin{array}{l}\text { CORINE Land Cover } \\
2006\end{array}$ & $\begin{array}{l}\text { landscape } \\
\text { derived from land cover } \\
\text { layer }\end{array}$ & $1: 100.000$ \\
\hline $\begin{array}{l}\text { Settlement } \\
\text { character } \\
\text { structure }\end{array}$ & $\begin{array}{l}\text { Framework settlement } \\
\text { types of the Czech } \\
\text { Republic (Löw et al., } \\
\text { 2005). }\end{array}$ & $\begin{array}{l}\text { categorical map of the } \\
\text { settlements types }\end{array}$ & $1: 500.000$ \\
\hline
\end{tabular}

\section{Methodological approaches used in the Czech Republic}

Another essential methodological difference of particular approaches is a different choice, processing and synthesis of the aforementioned input data. Every typology is assembled for a certain purpose, and that is why it selects different environmental factors and gives them different weight, according to the defined aims of the typology. The typologies of natural landscape types do not, therefore, logically use data on cultural factors; on the contrary, landscape classifications according to land use often omit several natural variables. In case of complex landscape typology it is nevertheless necessary to take both types of data into account. Such extensive sets of data force authors of typologies to rather subjective choices, whilst setting different weight to particular factors.

Several landscape typologies were developed in the Czech Republic, each aimed to fulfill different requirements. Table 2 shows the existing landscape classifications of the country:

Table 2: Selected landscape typologies published in last 40 years in the Czech Republic

\begin{tabular}{|l|l|l|l|l|l|}
\hline Typology & Authors & Method & $\begin{array}{l}\text { Environmental factors } \\
\text { used }\end{array}$ & $\begin{array}{l}\text { No. of } \\
\text { landscape } \\
\text { types }\end{array}$ & $\begin{array}{l}\text { No. of } \\
\text { landscape } \\
\text { units }\end{array}$ \\
\hline $\begin{array}{l}\text { Physical- } \\
\text { geographical } \\
\text { Regions }\end{array}$ & $\begin{array}{l}\text { Demek et al. } \\
1977)\end{array}$ & expert & $\begin{array}{l}\text { climate, geomorphology, } \\
\text { vegetation zones }\end{array}$ & 9 & 602 \\
\hline $\begin{array}{l}\text { Landscape character } \\
\text { assessment areas }\end{array}$ & $\begin{array}{l}\text { Muranský et al. } \\
(1977) \text { \& Nauman } \\
\text { et al. (1977) }\end{array}$ & expert & $\begin{array}{l}\text { land use, } \\
\text { aesthetical factors }\end{array}$ & 9 & - \\
\hline $\begin{array}{l}\text { Types of } \\
\text { contemporary } \\
\text { landscapes }\end{array}$ & $\begin{array}{l}\text { Kolejka, Romportl } \\
\text { Lipský, }\end{array}$ & expert & $\begin{array}{l}\text { climate } \\
\text { geology } \\
\text { geomorphology } \\
\text { land use }\end{array}$ & 417 & 1826 \\
\hline
\end{tabular}




\begin{tabular}{|l|l|l|l|l|l|}
\hline $\begin{array}{l}\text { Biogeographical } \\
\text { classification }\end{array}$ & Culek et al. (2005) & expert & $\begin{array}{l}\text { vegetation zones, } \\
\text { geomorphology, } \\
\text { pedogenetic substrate }\end{array}$ & 366 & 9186 \\
\hline Landscape types & Löw et al. (2005) & expert & $\begin{array}{l}\text { topography, land-use, } \\
\text { settlement }\end{array}$ & 164 & 2064 \\
\hline $\begin{array}{l}\text { Multivariate } \\
\text { classification of } \\
\text { cultural landscapes }\end{array}$ & $\begin{array}{l}\text { Chuman \& } \\
\text { Romportl (2010) }\end{array}$ & $\begin{array}{l}\text { cluster } \\
\text { analysis }\end{array}$ & $\begin{array}{l}\text { climate, soils, topography, } \\
\text { reconstrcted vegetation, } \\
\text { land cover }\end{array}$ & 11 & 897 \\
\hline Landscape types & Romportl (2010) & $\begin{array}{l}\text { object } \\
\text { based } \\
\text { image } \\
\text { analysis }\end{array}$ & $\begin{array}{l}\text { climate, geology, } \\
\text { topography, land cover }\end{array}$ & 79 & 1890 \\
\hline
\end{tabular}

\section{Physical-geographical Regions (Demek et al. 1977)}

Delineation of Physical-geographical regions represents one of the first modern approaches of landscape classification in the Czech Republic. A map of the natural landscape types was based on expert synthesis of overlaying thematic maps of environmental layers. The following key factors were chosen: vertical heterogeneity of relief, genetic type of relief, climatical regionalization and vertical vegetation zonation. All landscape types are indicated by a four-digit code, which represents the aforementioned factors. A total of 602 physical-geographical regions of nine basic typological groups were defined (Demek et al. 1977).

\section{Landscape Character Assessment Areas (Muranský et al. 1977, Nauman et al. 1977)}

A different approach of landscape classification was carried out by a team of landscape planners in 1977 (Muranský et al. 1977, Nauman et al. 1977). Although landscape character areas were defined according to statistical data on land-use, a crucial role was played by the expert opinion on aesthetical values of the countryside. Three basic landscape character areas were described: anthropogenic and man-made landscape, harmonic landscape with balanced ratio of both natural and cultural components, and relatively natural landscape with a predominance of natural elements. Spatial units of these general landscape types were classified according to their aesthetical value to three classes; therefore, 9 types of landscape character areas were delineated.

\section{Biogeographical regionalisation (Culek et al. 2005)}

Despite its name, Biogeographical regionalisation provides detailed complex landscape typology of the Czech Republic. Vegetation zones, geomorphology and pedogenetic substrate were used as environmental variables describing particular spatial units. Exceptional expert erudition and extensive field survey enabled the detailed definition of 366 landscape types called biochores, in 9186 spatial units in the country.

\section{Landscape typology (Löw et al. 2005)}

The complex typology of both natural and cultural landscape was handled by the team of J. Löw in 2005 within the project "Czech Landscape Typology". Recently, it has become the most often used landscape classification, which indicates a significant experience and erudition of the authors. They state, that the output of landscape typology does not have to be only scientifically precise, but mainly accessible to the general public and has to enable the identification of landscape types by its stakeholders and inhabitants. The authors, therefore, also worked with different data sources which are essential for a formulation of regional differences as to the landscape perception by the society. Classification is based on 
three input datasets, which present themselves a simple typology- general settlement landscape types, general land use types and general topography types.

\section{Types of contemporary landscape (Kolejka, Romportl, Lipský 2009)}

Lipský et al. (1997), Kolejka and Lipský (1999), Lipský and Romportl (2007) were, until recently, concerned with methodical and practical aspects of the cultural landscape typology. Within their projects, solving, mainly methodical issues of landscape classification, several samples of typological landscape maps of different spatial scales were developed. Final outputs of their approaches were published in Landscape Atlas of the Czech Republic (Hrnčiarová, Mackovčin, Zvara eds. 2009). Types of contemporary landscape were defined on a principle of physiognomic two-layer stratification of landscape which is formed by a primary (natural) and a secondary (anthropogenic) landscape structure. Natural structures were represented by climatic, geological and geomorphologic variables, whilst cultural structures were represented solely by land use. In total, 1826 spatial units of 417 landscape types in were defined.

\section{Multivariate classification of cultural landscapes (Chuman, Romportl, 2010)}

The first attempt to overcome expert-based step of landscape types delineation in the Czech Republic was carried out by Chuman and Romportl (2010). A method of divisive cluster analysis, based on objective repeatable procedures, was used for multivariate landscape classification. The territory of the country was divided by a regular georeferenced grid of $2 \times 2 \mathrm{~km}$. Each grid contained information concerning spatial representation of the following variables: topography, geological substrate, climatic region, reconstructed natural vegetation and land cover. A set of grids was analysed using divisive cluster analysis, and divided into hierarchically structured groups forming the landscape types, defined on the basis of different characteristics. The application of modified TWINSPAN algorithm (Roleček et al., 2009) yielded 11 divisions - national landscape types.

\section{Landscape typology using object oriented analysis (Romportl 2010)}

The latest effort of national landscape classification is based on principles of object oriented image analysis. Similarly to multivariate cluster analysis, exact datasets representing key environmental variables were used: mean annual temperature, parent geological substrate, altitude with vertical heterogeneity and land cover. Two essential steps make a difference compared to approaches mentioned above - principal component analysis of input quantitative datasets, and further object-based segmentation of first two channels of PCA. The main typological units, reflecting the primary spatial differentiation of landscape in terms of average annual temperature, altitude and slope, are represented by 6 framework types of natural landscapes. Their further segmentation, according to the geological conditions, led to delineation of 29 natural landscape types. Synthesis of natural and functional landscape types produced 79 types of present landscapes, considering actual land cover and its structure.

\section{DiSCUSSION}

The aforementioned landscape typologies were developed for different purposes: landscape planning (Löw et al. 2005), scientific overview of particular types (Demek et al. 1977, Kolejka et al. 2009), delineation of spatial units for landscape chase (Romportl 2010) 
or setting a framework for landscape character assessment (Muranský et al. 1977, Nauman et al. 1977). While some classifications pointed to uniqueness of particular landscape and draw attention to holistic approaches (e.g. Muranský et al. 1977, Löw et al. 2005), others emphasise the repeatability of environmental factors and use rather expert judgment (Kolejka et al. 2009) or semi-automatic segmentation (Chuman \& Romportl 2010, Romportl 2010). This situation is comparable to other European countries such Belgium (Van Eetvelde \& Antrop 2009), Austria (Peterseil et al. 2004), Germany (Haase 1989) or the United Kingdom ( Bunce et al. 1996)

Wascher (ed.) (2005) and Groom et al (2006) provide extensive overview of national landscape classifications in Europe except the Czech Republic. They concluded that the majority of the classifications were based on expert knowledge. Highly or semi-automated definition of landscape typological units were very limited and mostly combined with interpretation by experts of the automated result (Groom et al. 2006, Van Eetvelde \& Antrop 2009).

Although most of Czech typologies claim to be complex landscape classifications, the majority are mainly based upon natural factors, such as climate, geology, soils and elevation or vertical heterogeneity, whereas land cover is often used as the only cultural factor. The lack of suitable historical and cultural variables in defining landscape types and delineating character areas is mainly caused by the restrictions of the data describing these themes. Data on cultural, historical, archaeological, architectural and aesthetic features are highly fragmented, often specific to certain localities. They seldom have a consistent coverage of the entire country in sufficient detail and quality to integrate in nation-wide landscape classification (Van Eetvelde \& Antrop 2009).

Czech landscape typologies, introduced above, cover the whole territory of the country; nevertheless they differ very much in their spatial scale and number of both landscape types and units. Older expert-based landscape classifications were rather similar, defining low numbers of types and spatial units (Demek et al. 1977, Muranský et al. 1977), similarly to modern outputs using quantitative methods of geographical generalisation (Chuman \& Romportl 2010, Romportl 2010). These could serve as a general overview of national landscape types or landscape character areas. Extremely detailed typologies such as biogeographical regionalisation (Culek et al. 2005) or types of contemporary landscapes (Kolejka et al. 2009) provide comprehensive information for regional or even local landscape planning.

Comparison of methodological processing used for typologies is very difficult, therefore only several basic issues could be discussed. There is a paucity of information known about methodology of landscape classifications from the 1970's. Demek et al. (1977), Muranský et al. (1977) and Nauman et al. (1977) showed outstanding expert erudition, therefore their delineation of landscape types or landscape character areas is often used until recent times. However, they reflect the state of the Czech landscape more than 35 years ago, and because of unrepeatability of these approaches it is nearly impossible to update classification for recent conditions. The other two typologies (Culek et al. 2005, Kolejka et al. 2009) both combine exact data analysis and expert delineation of landscape types or bichores respectively. Moreover, both typologies - especially classification of Culek et al. (2005) are extremely detailed, therefore unbiased control is problematic as well. Kolejka et al. (2009) presents one of the first examples of GIS use in landscape classification development. The use of GIS to delineate and typify the spatial units and to visualize the result has been very common in other European states (Bastian 2000; Bunce et al. 1996; Lioubimtseva \& Defourny 1999; Van Eetvelde \& Antrop, 2009) since the 1990's, so logically has been implemented into methodology of Czech classifications. 
Landscape classification developed by Löw et al. (2005) differs from others by using qualitatively new information on character and history of settlement, which is undoubtedly a considerable contribution to the data backup of landscape typologies in the Czech Republic. However, the delimitation of boundaries of particular settlement types remains unclear because their definition is not stated anywhere. In addition, other input layers are not described in detail - categories of general land use types are clearly defined by their percentage ratio, however, it is not described in which spatial units the extent of land-use class was calculated. Secondly, some landscape topography types are controversial from a geomorphologist's point of view, and furthermore their precise formulation is not clear. Nevertheless, this often critically discussed output represents one of the most widely used landscape classification over the country.

Chuman and Romportl (2010) published new landscape typology based on a combination of GIS and multivariate analysis. Several studies using cluster analysis, namely Bunce et al. (1996), Jongman et al. (2006), Metzger et al. (2005), state that this approach is one of the most suitable for complex landscape classification. The 11 national landscape types obtained by TWINSPAN divisive cluster analysis show a well-defined pattern of distribution that relates to recogniable combinations of landscape features (Chuman \& Romportl 2010). Comparison with other typologies thus shows high similarity of defined spatial units. The distinct advantage of this method is the hierarchical system that is able to describe the national and regional levels, and a set of indicators that reveals what defines the levels (unlike other clustering techniques). The only constraint of the TWINSPAN classification is the limitation of it being only able to handle a maximum of 25,000 objects, which did not allow the authors to use a cell size of smaller than $2 \mathrm{~km} \times 2 \mathrm{~km}$ (regarding the extent of the Czech Republic). Larger cells cause the landscape units to look coarse (Chuman \& Romportl, 2010).

Romportl (2010) dealt with the issue of objective landscape classification by semiautomatic segmentation according to Mücher et al. (2003) based on object based image analysis (Hay et al. 2003). The aim was to reduce the subjective factor biasing classification, but expert knowledge was still necessary to apply this method. Instead of the use of RGB synthesis by Mücher et al. (2003), grids resulting from PCA analysis of input continual layers were used for segmentation. This allows setting the exact weight of particular channels in the process of multi-resolution segmentation (Romportl, 2010). This approach deals with the most problematic step of each typology - delimitation of concrete polygons representing particular landscape types - in an objective way. The disadvantage of this (like many other semi-automatic) approaches is a problematic identification of landscape units by their users and stakeholders.

To conclude this discussion, it can be stated that all basic approaches - holistic, expert based and semi-automated - have advantages and disadvantages. The automatic use of GIS in landscape classification creates rather complicated sliver polygons of landscape units, which is caused by integrating all the thematic maps (Mücher et al. 2010; Van Eetvelde \& Antrop 2009, Romportl 2010). Using the holistic approach to define the landscape units, it is possible to integrate and interpret both physical and cultural landscape components, based on the spatial configuration of the landscape types (e.g. Muranský et al. 1977, Löw et al. 2005).

The landscape units of the Czech landscape typologies are mainly based on natural features. Cultural and aesthetic themes are not used as differentiating variables but are additional descriptive ones added to the database. Also, perceptive characteristics are used rarely in the cartographic visualisation and presentation. 


\section{CONCLUSION}

Landscape classifications have become an object of interest for several scientific teams, as well as responsible officials or landscape users (stakeholders or decision makers) in the Czech Republic (Romportl 2010) and in Europe (Wascher ed. 2005). The aim of this study was to briefly describe and compare the most used and discussed national landscape classifications approaches in the Czech Republic. It is not possible to conclude that some landscape typology is better or worse than others. However, it can be concluded that some of them are more or less suitable for different aspects of use - landscape planning, monitoring of land-cover or biodiversity change, landscape character assessment etc. The Czech Republic needs to fulfill obligations resulting from the European Landscape Convention, and for that reason there is an objective demand for complex landscape typology. None of the landscape classifications mentioned above have been implemented into landscape politics or a system of landscape planning, so the requirement for a widely acceptable landscape typology represents a great challenge for Czech geographers.

\section{ACKNOWLEDGEMENTS}

This research was funded by the Research Plan MSM 0021620831 "Geographical systems and risk processes in the context of global changes and European integration" of the Czech Ministry of Education and the institutional resources of the Ministry of Education, Youth and Sports of the Czech Republic for the support of science and research.

\section{REFERENCES}

Bastian, O. (2000). Landscape classification in Saxony (Germany) - a tool for holistic regional planning. Landscape and Urban Planning, 50, pp. 145-155.

Bunce, R.G.H., Barr, C. J., Clarke, R. T., Howard, D. C., Lane, A. M. J. (1996). Land Classification for Strategic Ecological Survey. Journal of Environmental Management, 47(1), pp. 37-60. doi:10.1006/jema.1996.0034

Culek, M. et al. (2005). Biogeografické členění ČR II. Enigma, Praha, 589 p.

Demek, J., Quitt, E., Raušer, J. (1977). Fyzickogeografické regiony ČSR, Sborník ČSSZ, 1977, Vol. 2: 82, p. 89 - 99

Groom, G., Mücher, C.A., Ihse, M., Wrbka, T. (2006). Remote sensing in landscape ecology: experiences and perspectives in a European context. Landscape Ecology 21: pp. 391-408

Haase, G. (1989). Medium scale landscape classification in the German Democratic Republic. Landscape Ecology, 3(1), pp. 29-41. doi:10.1007/BF00157754

Hrnčiarová, T., Mackovčin, P., Zvara, I. (2009). Atlas krajiny České republiky. Ministerstvo životního prostředí ČR a Výzkumný ústav Silva Taroucy pro krajinu a okrasné zahradnictví, v. v. i., Praha-Průhonice, ISBN 978-80-85116-59-5, 352 p.

Chuman, T., Romportl, D. (2010). Multivariate classification analysis of cultural landscapes: An example from the Czech Republic. Landscape and Urban Planning, 98(34), pp. 200-209. doi:10.1016/j.landurbplan.2010.08.003 
Jongman, R., Bunce, R., Metzger, M., Mücher, C., Howard, D., Mateus, V. (2006). Objectives and applications of a statistical environmental stratification of Europe. Landscape Ecology 21: pp. 409-419. doi:10.1007/s10980-005-6428-0

Kolejka, J. (1999). Dynamická a aplikovaná geoekologie. Habilitační práce. Katedra chemie životního prostředí a ekotoxikologie PřF MU v Brně, 242 p.

Kolejka, J., Romportl, D., Lipský, Z. (2009). Typy současné krajiny. In: Hrnčiarová, T., Mackovčin, P., Zvara, I. (2009). Atlas krajiny České republiky. (352 p.). Ministerstvo životního prostředí ČR a Výzkumný ústav Silva Taroucy pro krajinu a okrasné zahradnictví, v. v. i., Praha-Průhonice, ISBN 978-80-85116-59-5

Kozák, J. et al. (2009). Soil Atlas of the Czech Republic. ČZU Praha, 2. upr. vyd., ISBN 978-80-213-2008-6, 150 p.

Lioubimtseva, E., Defourny, P. (1999). GIS-based landscape classification and mapping of European Russia. Landscape and Urban Planning, p. 44.

Lipský, Z. et al. (1997). Typologie a ochrana české kulturni krajiny. Závěrečná zpráva výzkumného projektu GAČR, č. 206/95/0959. Ústav aplikované ekologie, Lesnická fakulta České zemědělské univerzity.

Lipský, Z., Romportl, D. (2007). Typologie krajiny v České republice a zahraničí - stav problematiky, metody a teoretická východiska. Geografie - Sborník ČGS, Vol. 112, pp. 61 $-83$

Löw, J. et al. (2005). Typologie české krajiny, Závěrečná zpráva projektu VaV 640/01/03 za roky 2003 - 2005. Löw a spol. s.r.o. \& MŽP ČR, Brno

Metzger, M. J., Bunce, R. G. H., Jongman, R. H. G., \& Mücher, C. A. (2005). A climatic stratification of the environment of Europe. Global Ecology and Biogeography, pp. 549563. doi:10.1111/j.1466-822x.2005.00190.x

Muranský, P. a kol. (1977). Hodnocení krajiny a jego využití v plánovací a projektové technice. Architektura ČSR, roč. XXXVI, Vol. 9 - 10, Praha, pp. 390 - 398

Mücher, C. A., Bunce, R. H. G., Jongman, R. H. G., Klijn, J. A., Koomen, A. J. M., Metzger, M. J., Wascher, D. M. (2003). Identification and characterisation of Environments and landscapes in Europe. Alterra - rapport 832, Wageningen, 120 p.

Mücher, C. a., Klijn, J. a., Wascher, D. M., \& Schaminée, J. H. J. (2010). A new European Landscape Classification (LANMAP): A transparent, flexible and user-oriented methodology to distinguish landscapes. Ecological Indicators, 10(1), pp. 87-103. doi:10.1016/j.ecolind.2009.03.018

Nauman, P. a kol. (1977). Krajinářské hodnocení z hlediska teoretického a metodologického, Architektura ČSR, roč. XXXVI, č. 9 - 10, Praha, pp. 386 - 390

Neuhäuslová, Z. et al. (1999). Mapa potenciální přirozené vegetace $\check{C} R$. Academia, Praha, ISBN 80-200-0687-7, 342 p.

Palang, H., Printsmann, A., Konkoly-Gyuro, E., Urbanc, M., Skowronek, E., Woloszyn, W. (2006). The Forgotten Rural Landscapes of Central and Eastern Europe. Landscape Ecology /2006/ 21: pp. 347-357. DOI 10.1007/s10980-004-4313-X

Peterseil, J. (2004). Evaluating the ecological sustainability of Austrian agricultural landscapes - the SINUS approach. Land Use Policy, 21(3), pp. 307-320. doi:10.1016/ j.landusepol.2003.10.011

Pinto-Correia, T., Gustavsson, R., Pirnat, J. (2006). Bridging the Gap between Centrally Defined Policies and Local Decisions - Towards more Sensitive and Creative Rural 
Landscape Management. Landscape Ecology /2006/ 21: pp. 333-346, DOI 10.1007/s10 980-005-4720-7

Romportl, D., Chuman, T. (2007). Proposal method of landscape typology in the Czech republic. In Dreslerová, J., (ed.): Journal of Landscape Ecology. 0. číslo časopisu CZIALE, Brno, ISBN 978-80-86386-97-3

Romportl, D. (2010). Typologie krajiny České republiky. Dizertační práce. Katedra fyzické geografie a geoekologie PřF UK v Praze.

Tolasz, R. et al. (2007). Climate Atlas of Czechia. 1. vyd. Praha: Český hydrometeorologický ústav; Olomouc: Univerzita Palackého v Olomouci, 2007. 255 p, il., tab., mapy. ISBN 9788086690261 (ČHMU). ISBN 9788024416267 (UP).

USGS - SRTM (2000). Digital Elevation Model. NASA, c. 2006. Retrieved October 10, 2009 from <http://www2.jpl.nasa.gov/srtm/l>

Van Eetvelde, V., Antrop, M. (2009). A stepwise multi-scaled landscape typology and characterisation for trans-regional integration, applied on the federal state of Belgium. Landscape and Urban Planning, 91(3), pp.160-170. doi:10.1016/j.landurbplan.2008.12.008

Wascher, D.M., ed. (2005). European Landscape Character Areas - Typologies, Cartography and Indicators for the Assessment of Sustainable Landscapes. Final Project Report as deliverable from the EU's Accompanying Measure project European Landscape Character Assessment Initiative (ELCAI), (4.2.2), x + 150 pp..

Zoubek, J. et al. (2003). Atlas Geo $\check{C} R$ 500. CD-ROM - soubor geovědních map. Česká geologická služba, Praha 